Article

\title{
Examining Generation Z's Attitudes, Behavior and Awareness Regarding Eco-Products: A Bayesian Approach to Confirmatory Factor Analysis
}

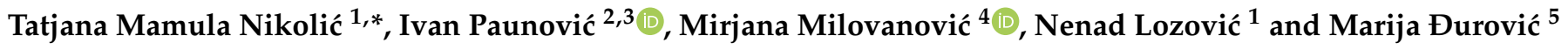 \\ 1 Faculty of Management, Metropolitan University, Tadeuša Košćuška 63, 11000 Belgrade, Serbia; \\ nenad.lozovic.4328@metropolitan.ac.rs \\ 2 CENTIM-Centrum für Entrepreneurship, Innovation und Mittelstandsmanagement, Bonn-Rhein-Sieg \\ University of Applied Sciences, 53359 Rheinbach, Germany; ivan.paunovic@h-brs.de \\ 3 Campus Rothenburg, Ansbach University of Applied Sciences, 91541 Rothenburg ob der Tauber, Germany \\ 4 Banja Luka College, Miloša Obilića 30, 78000 Banja Luka, Republic of Srpska, Bosnia and Herzegovina; \\ mirjana.milovanovic@blc.edu.ba \\ 5 Civil-Engineering School “Branko Žeželj”, Hajduk Stankova, 11000 Belgrade, Serbia; \\ marija.djurovic@zezelj.edu.rs \\ * Correspondence: tatjana.mamula@metropolitan.ac.rs
}

check for updates

Citation: Nikolić, T.M.; Paunović, I.; Milovanović, M.; Lozović, N.; Đurović, M. Examining Generation Z's Attitudes, Behavior and Awareness Regarding Eco-Products: A Bayesian Approach to Confirmatory Factor Analysis. Sustainability 2022, 14, 2727. https:// doi.org/10.3390/su14052727

Academic Editors: Lynn Kahle and Eda Gurel-Atay

Received: 21 January 2022

Accepted: 22 February 2022

Published: 25 February 2022

Publisher's Note: MDPI stays neutral with regard to jurisdictional claims in published maps and institutional affiliations.

Copyright: (C) 2022 by the authors. Licensee MDPI, Basel, Switzerland. This article is an open access article distributed under the terms and conditions of the Creative Commons Attribution (CC BY) license (https:// creativecommons.org/licenses/by/ $4.0 /)$.

\begin{abstract}
The research examines Generation Z's (Gen Z's) attitudes, behavior and awareness regarding sustainability-oriented products in two European countries, located in the region of Western Balkans, Bosnia-Herzegovina and Serbia. The research deploys generational cohort theory (GCT) and a quantitative analysis of primary data collected through an online questionnaire among 1338 primary, high school and university students, all belonging to Generation Z. It deploys a Confirmatory Factor Analysis (CFA) by running both Maximum Likelihood (ML) and Markov Chain Monte Carlo (MCMC) procedures, the latter being suitable for binary variables, which have been deployed in the study. The results of MLCFA provide evidence that there is a statistically significant and relatively strong relation between sustainability and circular economy attitudes (SCEA) and sustainability and circular economy behavior (SCEB), while there is a statistically insignificant and relatively weak relation between sustainability and circular economy behavior (SCEB) and circular economy awareness (CEW). The results of the BCFA, which is based on MCMC procedure, are similar to the results based on a rather commonly used MLCFA procedure. The results also confirm that Gen $\mathrm{Z}$ knows more about the companies which recycle products than it does about the $C E$ as a concept, while the vast majority is concerned about the future of the planet and is motivated to learn more about the CE through CE and various awareness-raising measures.
\end{abstract}

Keywords: generation Z; generational cohort; consumer behavior for sustainability; circular economy; eco-products; eco-certification; environmental certification; sustainability-oriented behavior; attitudebehavior gap for sustainability; Bayesian CFA; BCFA; Markov chain Monte Carlo

\section{Introduction}

Understanding the mutual relation between attitudes and behavior, as well as awareness and behavior is crucial for extending the knowledge on how circular economy brands can successfully create awareness and alter consumer behavior for closing the loop inside a circular economy. In addition, including generational cohorts as a basis for the creation of theoretical models can extend our understanding of sustainable consumption and provide marketers with applicable theories for use in the everyday business practice of selling eco products. Therefore, the present research extends consumer behavior theory by applying the Generational Cohort Theory (GCT) through observing the ration Z (those born between 1995 and 2010) as the youngest generational cohort of active consumers on the market. The goal of the research has been to examine the mutual relation between sustainability and 
circular economy attitudes and behavior and circular economy awareness of Generation Z related to eco products.

There is an abundance of evidence that in certain market contexts, cohort membership is a better predictor than other demographic variables (gender, education, religion), therefore paving the way for the application of the GCT [1-3]. However, generational cohorts differ globally in different countries. There are similarities between U.S. and European generational cohorts, as well as between those in China, India, South Korea and Japan [4]. This research defines the border between generations $\mathrm{Y}$ and $\mathrm{Z}$ in line with the data from the official statistics office of the Republic of Serbia, which is roughly in line with other sources $[5,6]$. It should be noted, however, that these exact years when one generational cohort ends and another begins are not definitive and are open for debate: Generation $\mathrm{Z}$ (those born from 1995 to 2010, making up 16\% of the total population in the Republic of Serbia), generation Y (those born between 1980 and 1994, making up 20.5\% of the population), generation X (born between 1965 and 1979, making up 20.5\% of the population) and baby boom Generation (born between 1945 and 1964, making up 25\% of the total population) [5]. The share of Generation Z members in the Republic of Srpska (entity in Bosnia and Hercegovina) is $17 \%$. Globally, as many as 2.47 billion people belong to Generation Z, representing a considerable market force [7]. Contemporary marketers, wishing to win over Generation $\mathrm{Z}$ for their high-tech products, should not only pay attention to innovativeness as a strategic lever but also to their own credibility and consistency between words and actions, as these values are highly ranked by Gen Z [8,9]. Moreover, according to a Global Web Index survey (GWI, 2020), 64\% of Gen $Z$ and $63 \%$ of GenY are willing to pay more for an "environmentally friendly" product. Generation $Z$ values social and environmental issues highly, while during the COVID-19 pandemic, their expectations concerning mental health and anxiety-related issues had increased significantly [10]. Furthermore, recent reports confirm that despite the pandemic, $35 \%$ of Generation $Z$ are interested in the environment and sustainability as their priority, while they are increasingly inclined to accept a healthy routine and adopt more ethical choices [4]. These previous studies point to the need to create a better and more precise understanding of the mechanisms which lay behind the consumer behavior of Generation $\mathrm{Z}$ regarding eco products. Gen $\mathrm{Z}$ wants to see actionable plans and measurable progress regarding sustainability, ranging from developing company-wide environmental policies to making smart climate-related investments [11]. However, in order to do this, companies need to understand the mechanisms which influence the Gen $Z$ consumer behavior related to eco products. This study therefore examines the impact of sustainability and circular economy attitudes as well as circular economy awareness on consumer behavior of Generation $\mathrm{Z}$ regarding eco products. The created model tests the mediating role of circular economy awareness in these relationships.

Both attitudes as well as awareness are important categories for marketers trying to alter consumer behavior [12]. While attitudes are in the domain of affective internal factors influencing environmental behavior, awareness is shown to mediate between cognitive and affective domains [13]. Present research extends this research by exploring the relation between attitudes, behavior and awareness of Gen $\mathrm{Z}$ as a specific generational cohort. Attitudes among consumers regarding the circular economy can vary significantly [14,15], which is why awareness has been researched, in addition to attitudes and behavior, as already identified important factors in environmental research. The impact of awareness of environmental issues on behavior, especially consumer behavior, has been established in the previous literature and supported by qualitative data [16,17]. Awareness of environmental issues also impacts consumers in the sense that they engage in public endorsement and recommendation behavior of environmentally sound products [18]. Consumer behavior which is geared towards sustainability-oriented products is often correlated with the awareness about the impact of one's own purchasing decision on the environment [19]. In addition, there is evidence that independently certified circular economy products both raise awareness among the consumers, as well as provide a reference for future product innovation and management [20]. 
Previous sustainability-oriented behavior research has been based on cognitive dissonance theory [21,22], where the link and occasional dissonance between environmental attitudes and behavior seem to attract considerable attention $[23,24]$. The dissonant relationship between environmental attitudes and behavior has also been named an attitudebehavior gap $[25,26]$. The goal of each individual is to close the discrepancy between own attitudes and behavior by finding a good match in an attempt to keep the balance between the two. Previous research has identified a gap in our understanding of how do differing experiences, perceptions, awareness and moral responsibility affect pro-environmental behavior, extending the understanding of sustainability-oriented behavior beyond the attitude-behavior nexus [27]. The present study seeks to move this discussion forward and therefore aims at identifying, contextualizing and measuring attitudes, behavior and awareness regarding eco products and their mutual interrelations, thereby examining the following research hypotheses:

Hypothesis 1 (H1A): There is a statistically significant correlation between Sustainability and circular economy attitudes (SCEA) and Sustainability and circular economy Behavior (SCEB).

Hypothesis 2 (H2A): There is a statistically significant correlation between Sustainability and circular economy attitudes (SCEA) and Circular economy awareness (CEW).

Hypothesis 3 (H3A): There is a statistically significant correlation between Sustainability and circular economy behavior (SCEB) and Circular economy awareness (CEW).

These three research hypotheses are better contextualized in more detail in the literature in Section 2.1. and summarized in the research question (RQ) 1. The three hypotheses are presented as an alternative hypothesis, while the null hypothesis has not been presented for the sake of conciseness.

\section{Literature Review}

\subsection{Eco-Products: Definitions and Examples of Products for Sustainability and Circular Economy}

Eco-products are characterized by the integration of environmental considerations into the process of product development- from ideation to distribution to purchase and endof-life [28]. Newer approaches to eco-product design emphasize cradle-to-cradle design and circular economy approach [29]. Some examples include the use of biodegradable plastics [30] as well as biodegradable composite materials [31], which are still to be scaled from laboratory pilot studies to widespread usage on the way to truly circular economy. Some other examples include LED lighting solutions for efficient electricity use [32], efficient jeans production (less water usage by water recycling, eco-friendly dies) and recycling as well as repair service possibilities [33]. Food products that use by-products of previous production processes are also another example, e.g., using grain, which is a by-product from beer-brewing process for the production of functional batters [34].

\subsection{Generation $Z$ as an Upcoming Consumer Force and Its Place within the Sustainable Development}

Generation $\mathrm{Z}$ is shown to be more open-minded and culturally aware than the other, older generational cohorts, as a result of its constant online presence as a digital native and growing up in the VUCA world $[10,11]$. An international study of Generation Z noted that this cohort is more involved in different types of activism-Gen $\mathrm{Z}$ is tuned for voluntarism and activism, cares about improving the world and actively chooses brands that work to make the world a better place $[35,36]$. Therefore, brands that emphasize health and wellbeing could prevail among new generation consumers in times of pandemics. Generation $\mathrm{Z}$ is constantly active in the online space by sharing, co-creating, reading, checking, comparing, analyzing and evaluating options, information and ideas in order to ensure they are making the most out of the whole daily experience [36-38]. Keeping these findings in mind, market-oriented companies need to adapt to new generations of consumers by adapting 
their activities to the principles of joint value creation of all participants (co-creation) inside a sustainable business concept. Previous literature does not provide enough evidence on the best way to communicate with Generation Z, especially regarding eco-products. For example, what is the relation between attitudes, awareness and consumer behavior regarding eco products? A better understanding of the relation between these three variables can provide solid grounds for designing attractive marketing strategies, which are designed to communicate effectively with Generation Z. This is important, as there is a lack of research pertaining directly to Generation $Z$, as it is the youngest generational cohort today on the market. Generation $\mathrm{Z}$ is a very diverse cohort in terms of demographic and personal interests. They are exposed to wide range of cultural perspectives and being unique and different is important characteristic for them [35]. Although the pursuit of uniqueness is a distinctly adolescent characteristic which is developmental stage of most members of Generation Z, some characteristics are clearly distinct compared to other generations. They value health, well-being and sustainability but at the same time have more pragmatic and cautious attitude to money compared to millennials. Previous research confirms that value consciousness and convenience are the dominant shopping orientations that drive Gen $\mathrm{Z}$ consumers, especially in online shopping [39-41], as well as accessibility and eco-friendly packaging [42-44]. However, there are also opposing findings, stating that the packaging as well as its recyclability play a rather marginal role in Generation Z's purchasing behavior regarding groceries such as milk [45]. In order to better understand shopping decisions regarding eco products of Generation $Z$, the following research question (RQ) was proposed:

RQ1: How are Gen Z's attitudes, awareness and behavior regarding eco-products mutually related?

\subsection{Sustainability and Circular Economy Attitudes as a Predictor of Environmentally Significant Behavior in Gen Z}

Generation Z's views of the circular economy efforts of fast fashion brands vary from positive (it creates value) to negative (hypocritical) to indifferent (not relevant) [46]. This demonstrated that Generation Z's attitudes are not necessarily coherent within the cohort but differing and often conflicting views exist within the generational cohort. Research on Generation $Z$ attitudes towards the circular economy demonstrates that there are considerable differences between Generation $Z$ cohorts across different countries and educational systems. For example, research in Romania has confirmed that the circular economy attitudes of Generation $Z$ are statistically significantly lower than that of Generation $X$ members: both regarding waste separation as well as recycling in general. [47]. In this sense, Generation $\mathrm{Z}$ is in need of further awareness-raising and education measures in order to engage them with circular economy. In other countries, the research of Generation $Z$ students has found that they have more positive circular economy attitudes and behaviors than other age groups [48]. These contradicting results call for more international comparative research regarding Generation $\mathrm{Z}$ awareness and attitudes but also point to the need to create theoretical models that can function and be applied in different types of social contexts. Previous research posits that attitudes impact the awareness as well as behavior, where attitudes are an internal factor of ecological behavior and a standard element in the theory of planned behavior [48-50] in order to understand better the phenomenon of sustainability and circular economy attitudes, the following research question was drafted:

RQ2: To what degree are single observable variables of Gen Z's sustainability and circular economy attitudes (SCEA) relevant for the SCEA as a latent construct?

\subsection{Sustainability and Circular Economy-Oriented Behavior in Different Generational Cohorts}

The link between attitudes and behavior in sustainable consumption has been researched from a wide range of perspectives and in a wide range of industries; however, research in tourism and food industries appears to attract significant attention [34,51-54]. 
In addition, a significant portion of literature deals with the aforementioned phenomena from a generational cohort perspective. For example, regarding Generation Z, the following predictors of environmentally significant behavior have been researched in the literature: environmental and circular economy knowledge, skills, attitudes and values [55-58]. Regarding the baby boomer generation, they have an attitudinal tendency to expect that environmental issues are of relevance for younger, future-oriented generations and not for themselves, which is in contrast with the members of the younger, Generation Z, who expect environmental and sustainability issues to be addressed by organizations and the whole of society on an ongoing basis [36,59]. The present research builds on the notion that attitudes and behavior differ between generations [60], thereby selecting a context of the single most under-researched generation (Generation Z) as a research context for understanding sustainability- and circular economy-oriented behavior. Therefore, the following hypothesis was put forward:

RQ3 : To what degree are single observable variables of Gen Z's sustainability and circular economy behavior (SCEB) relevant for the SCEB as a latent construct?

\subsection{Generation Z's Awareness of Circular Economy Challenges and Issues}

Previous research on sustainability awareness of Generation $\mathrm{Z}$ has not yielded consequent and unambiguous results. Some critical research streams question the role of Generation $\mathrm{Z}$ as supposed sustainability revolutionaries, as they have been shown to be the generation least aware of the problem of over-tourism in tourist destinations, compared to generations $X$ and $Y$ [61]. Moreover, Generation $Z$ females have been identified as being the least environmentally conscious group among Generation $X$ and Generation Z [62]. Previous research has confirmed that environmental awareness alone does not lead to proenvironmental behavior in all situations but also that other predictors can come into play, as consumer behavior is a complex phenomenon. For example, it has been demonstrated that environmental awareness leads to energy savings in households only for actions and behaviors which do not incur additional costs, e.g., lowering the temperature in the house while absent [63]. This means that price sensitivity is sometimes more important than awareness of certain sustainability issues.

The research on Generation Z's environmental awareness has provided segmentation of the American Generation $Z$ regarding sustainable food [64]. While these results are important as a practice-oriented study, little is known on the role of circular economy awareness and its relation to consumer behavior regarding eco-products among Generation $Z$. There is evidence that, because Generation $Z$ is being educated in school about circular economy issues, they also notice the lack of awareness, concern and change on this issues in the consumer markets where they are active [65]. However, a lack of understanding and awareness of the waste management process has also been identified to be the major reason for not engaging in customer behavior in line with circular economy principles among Generation Z [48]. Having in mind the often-stated lack of awareness of circular economy, the hypothesis regarding the circular economy awareness construct has been posed below.

RQ4 : To what degree are single observable variables of Gen Z's circular economy awareness (CEW) relevant for the CEW as a latent construct?

\section{Methodology}

The current study aims at uncovering how Gen Z's attitudes, behavior and awareness for sustainability and circular economy are mutually related as well as what are determinants of Gen Z's sustainability and circular economy attitudes and behavior, as well as determinants of their circular economy awareness. The study deploys a quantitative method of data analysis in order to tackle the four research questions, which have been proposed in the literature review section. Software packages SPSS v26 [66] and AMOS v24 [67] were deployed for the building of the database and data processing as well as for 
conducting descriptive statistics analysis and Confirmatory Factor Analysis. The research deployed Confirmatory Factor Analysis with both Maximum Likelihood (ML), a frequentist approach, as well as Markov Chain Monte Carlo (MCMC), a Bayesian approach. The use of MCMC, the Bayesian approach was necessitated by the structure of the data, where a majority of the manifest variables were binary (2-point scale) or ordinal (3-point scale), making ML analysis not reliable. The decision to design variables as binary was made in order to facilitate data collection among Gen $\mathrm{Z}$ and thereby enhancing the sample size, as well as the reliability of the data.

\subsection{Data Collection and Study Sample}

The study is based on data collected through an online survey from 1 February 2021 to 16 February 2021 with an aim of exploring awareness, attitudes and behavior in the domain of sustainability and circular economy. The link to the respondent-completed online questionnaire programmed in Google Forms was distributed to students by their professors through different media. The professors who distributed the questionnaire were all part of the author's and co-authors' professional networks. There were students from 2 primary schools, 3 secondary schools and 4 higher education schools in Serbia and 6 primary schools, 3 secondary schools and 2 higher education schools in the Republic of Srpska entity in Bosnia and Herzegovina. The study sample has included 1338 primary, high-school and university students from the Republic of Serbia $(\mathrm{N}=872)$ and the Republic of Srpska (Bosnia and Herzegovina) $(\mathrm{N}=466)$ who belong to Generation $Z$ (youth born between 1995 and 2010). The sample consisted predominantly of females (61\%) between 11 and 26 years old and attending primary school (33\%), high school (27\%) or faculty (40\%). Table 1 shows the demographic profile of the sample. Having in mind the aforementioned sampling and questionnaire solicitation method (referral by professors to their students), there were no issues with low response rates, as is often the case in postal or mail solicited surveys. The goal has been to obtain an absolute number of more than 1000 responses, in order to ensure sample validity, as proposed previously by Veal et. al [68].

Table 1. Sample profile.

\begin{tabular}{ccc}
\hline Variable & Category & Percentage \\
\hline Gender & Male & $39 \%$ \\
& Female & $61 \%$ \\
Age & $12-14$ & $30 \%$ \\
& $15-18$ & $30 \%$ \\
Education & $18-25$ & $40 \%$ \\
& & $33 \%$ \\
& Elementary & $27 \%$ \\
Country (territory) & High school & $40 \%$ \\
& Faculty & $35 \%$ \\
& Bosnia and Herzegovina (Rep. of Srpska) & $65 \%$ \\
\hline
\end{tabular}

\subsection{Measures}

For the purpose of the current study, three constructs were analyzed: Sustainability and circular economy attitudes (SCEA) and Sustainability and circular economy behavior (SCEB) and Circular economy awareness (CEW). Sustainability and circular economy attitudes were measured through importance attached to the fact that certain companies take care about sustainability (3-point scale), openness to the education about the circular economy (2-point scale), as well as the presence of worry about the future of the planet (2-point scale). Sustainability and circular economy behavior were measured by asking students if they aspire to buy eco-labeled products (3-point scale), their willingness to pay 
more for eco products (3-point scale) and readiness to share experience about eco products on social media (3-point scale). In measuring Circular economy awareness, students were asked if they are aware of companies that recycle products (2-point scale) and whether they know what circular economy is (2-point scale). Questions for all three constructs are shown in Table 2 below.

Table 2. Constructs and list of tested items.

Sustainability and Circular Economy Attitudes (SCEA)

- $\quad$ SCEA 1: Is it important to you that the companies whose products you buy take care of you both as consumers as well as to take care of sustainability?

- $\quad$ SCEA 2: Would you like to be more informed about the circular economy and its importance both through education as well as through various campaigns?

- $\quad$ SCEA 3: Are you worried about the future of the planet?

Sustainability and circular economy behavior (SCEB)

- $\quad$ SCEB 1: Do you aspire to buy eco-labeled products?

- $\quad$ SCEB 2: Are you willing to pay more for eco products?

- $\quad$ SCEB 3: Do you share experiences about eco products on social media?

\section{Circular economy awareness (CEW)}

- $\quad$ CEW 1: Have you heard of some companies taking back their used products for recycling and re-inserting them into the production process?

- CEW 2: Do you know what a circular economy is?

\section{Results}

In order to examine the mediating role of circular economy awareness in the impact of sustainability and circular economy attitudes on Gen Z's consumer behavior regarding eco products, we conducted the structural equation model analysis. The latent variables were tested for convergence validity and the structural equation model was tested for discriminant validity. Both tests confirmed the validity of the model.

\subsection{Measurement Model and Descriptive Statistics}

The univariate normality of data was examined using the Shapiro-Wilk test, which indicated a violation of normal distribution assumption (see Table 3). Additionally, Table 3 contains the means and standard deviations of all measures using the posterior values obtained from the Bayesian estimation.

Table 3. Shapiro-Wilk normality test and Psychometric properties.

\begin{tabular}{ccccccc}
\hline & $\mathbf{N}$ & $\begin{array}{c}\text { Test of Normality } \\
\text { SW Test } \\
\text { (Statistic) }\end{array}$ & Minimum & Maximum & Average & $\begin{array}{c}\text { Std. } \\
\text { Deviation }\end{array}$ \\
\hline CEW1 & 1338 & $0.368^{* *}$ & 0.39 & 0.51 & 0.46 & 0.01 \\
CEW2 & 1338 & $0.462^{* *}$ & 0.21 & 0.32 & 0.27 & 0.01 \\
SCEA1 & 1338 & $0.508^{* *}$ & 1.59 & 1.76 & 1.68 & 0.02 \\
SCEA2 & 1338 & $0.483^{* *}$ & 0.73 & 0.83 & 0.78 & 0.01 \\
SCEA3 & 1338 & $0.529^{* *}$ & 0.86 & 0.93 & 0.90 & 0.01 \\
SCEB1 & 1338 & $0.378^{* *}$ & 0.85 & 0.98 & 0.91 & 0.01 \\
SCEB2 & 1338 & $0.328^{* *}$ & 1.03 & 1.16 & 1.10 & 0.02 \\
SCEB3 & 1338 & $0.448^{* *}$ & 0.25 & 0.37 & 0.31 & 0.02 \\
\hline ** denotes significance at $p<0.01$. & & & &
\end{tabular}

For the purpose of testing discriminant analysis of the measurement model, the square root of the AVE and heterotrait-monotrait (HTMT) ratio of correlations were analyzed. The 
square roots of the AVE estimate for awareness were greater than the correlation with all other constructs, which confirmed discriminant validity for this construct. On the other hand, attitudes and behavior did not confirm discriminant validity based on this measure. Table 4 presents the correlation among the constructs and the square root of the AVEs. Additionally, discriminant validity was assessed based on the multitrait-multimethod matrix: the heterotrait-monotrait (HTMT) ratio of correlations. If the values are lower than the HTMT value of 0.85 , discriminant validity can be confirmed. As shown in Table 4, all values are below 0.85 .

Table 4. Discriminant validity: correlations, the square roots of AVEs and Heterotrait-Monotrait (HTMT) Ratio of Correlations.

\begin{tabular}{cccc}
\hline & CEW & SCEA & CEB \\
\hline CEW & $0.56^{\mathrm{a}}$ & $0.40^{\mathrm{c}}$ & $0.41^{\mathrm{c}}$ \\
SCEA & $0.30^{\mathrm{b}}$ & $0.60^{\mathrm{a}}$ & $0.79^{\mathrm{c}}$ \\
SCEB & $0.30^{\mathrm{b}}$ & $0.79^{\mathrm{b}}$ & $0.70^{\mathrm{a}}$ \\
\hline
\end{tabular}

"a" denotes the square root of average variance extracted; " $\mathrm{b}$ " denotes the correlations between the constructs.; " $\mathrm{c}$ " denotes the heterotrait-monotrait values.

\subsection{Maximum Likelihood Confirmatory Factor Analysis (MLCFA), a Frequentist Approach}

In the next step, a Maximum likelihood First-order factor analysis was deployed in order to determine the relationship between CEW, SCEA and SCEB, as well as the greatest contributors among manifest variables, for each latent dimension. The specified model is presented in Figure 1.

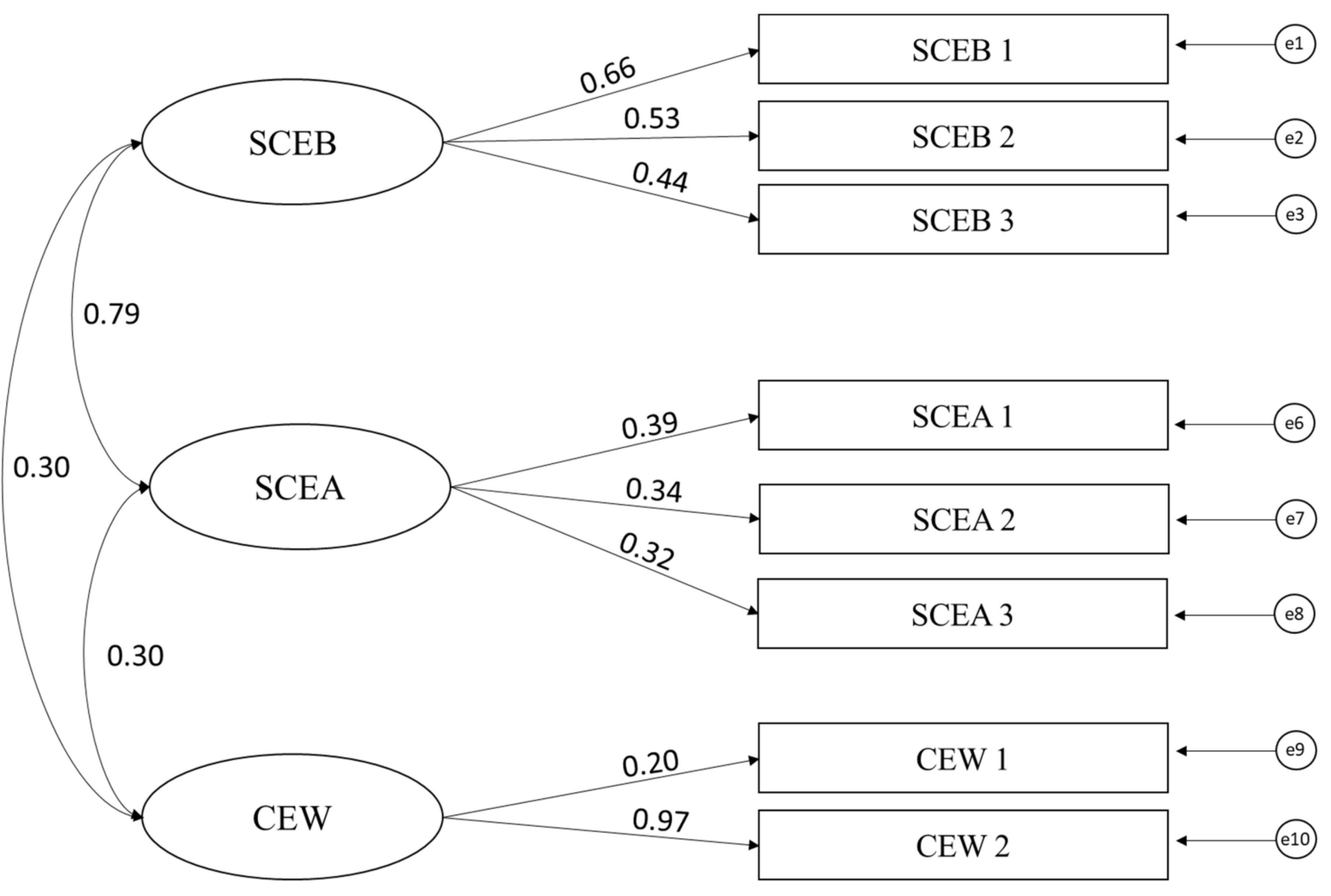

Figure 1. The first order factor model with specified correlations and standardized regression coefficients.

The fit of the model was tested with the following parameters: chi-square statistic $\left(\chi^{2}\right)$, CFI, NFI, TLI, and RMSEA. The value of the chi-square statistic $\left(\chi^{2}\right)$, with 17 degrees of freedom (d.f.) is $\chi^{2}=42.955$, with a significance value of $p=0.000$ and a ratio $\chi^{2} /$ d.f. $=2.527$. 
Since the chi-square test should have values that are lesser than 5 , we can conclude that the model fit is at a satisfactory level. This finding was additionally confirmed with parameter RMSEA that has a value less than 0.5 and CFI, NFI and TLI that have values higher than 0.9 (RMSEA $=0.034, \mathrm{CFI}=0.960, \mathrm{NFI}=0.938, \mathrm{TLI}=0.916$ ). Taking all parameters into consideration, it can be confirmed that the tested SEM model is on a satisfactory level.

The only significant positive correlation is between SCEA and SCEB $(r=0.79, p=0.00)$. On the other hand, CEW and SCEB $(r=0.30, p=0.07)$ and SCEA and CEW $(r=0.30, p=0.08)$ are not significantly associated. Correlations between factors are represented in Table 5. Based on these results, Hypothesis H1A, that there is a statistically significant correlation between Sustainability and circular economy attitudes (SCEA) and Sustainability and circular economy behavior (SCEB), was accepted. On the other hand, Hypothesis H2A was rejected and instead, $\mathrm{H}_{0}$ Hypothesis was accepted - that there is no statistically significant correlation between Sustainability and circular economy attitudes (SCEA) and Circular economy awareness (CEW). Based on the above results, Hypothesis H3A was rejected and a null hypothesis was accepted instead $\left(\mathrm{H}_{3}\right)$ - that there is no statistically significant correlation between Sustainability and circular economy behavior (SCEB) and Circular economy awareness (CEW).

Table 5. Correlations of the first-order factor model, are presented in Figure 1.

\begin{tabular}{|c|c|c|c|c|c|c|c|}
\hline & & & $\begin{array}{l}\text { Unstandardizes } \\
\text { Estimate }\end{array}$ & $\begin{array}{l}\text { Standardized } \\
\text { Estimate }\end{array}$ & $\begin{array}{l}\text { Approximate } \\
\text { Standard Error }\end{array}$ & $\begin{array}{c}\text { Critical } \\
\text { Ratio }\end{array}$ & $p$ \\
\hline SCEA & $<->$ & SCEB & 0.078 & 0.787 & 0.010 & 7.996 & 0.001 \\
\hline SCEA & $<->$ & CEW & 0.008 & 0.298 & 0.005 & 1.791 & 0.08 \\
\hline CEW & $<->$ & SCEB & 0.011 & 0.304 & 0.006 & 1.784 & 0.07 \\
\hline
\end{tabular}

When it comes to the determinants of tested constructs, almost all manifest variables were significantly contributing to the explanation of its latent dimensions. The standardized regression coefficients of the model are shown in Table 6. CEW 2 has higher loading on the CEW $(b=0.97)$ compared to CEW $1(b=0.20)$ but borders on being significant. SCEA 1 is the highest saturated manifest variable on SCEA $(b=0.39)$, followed by SCEA $2(b=0.34)$, SCEA $3(b=32)$. Finally, SCEB 1 has the highest loading on SCEB $(b=0.66)$, followed by SCEB $2(b=0.53)$ and SCEB $3(b=0.44)$.

Table 6. Regression weights of the latent dimensions.

\begin{tabular}{|c|c|c|c|c|c|c|c|}
\hline & & & $\begin{array}{l}\text { Unstandardized } \\
\text { Estimate }\end{array}$ & $\begin{array}{l}\text { Standardized } \\
\text { Estimate }\end{array}$ & $\begin{array}{l}\text { Approximate } \\
\text { Standard Error }\end{array}$ & $\begin{array}{l}\text { Critical } \\
\text { Ratio }\end{array}$ & $p$ \\
\hline CEW 1 & $<-$ & CEW & 1.000 & 0.201 & & & \\
\hline CEW 2 & $<-$ & CEW & 4.281 & 0.968 & 2.328 & 1.839 & 0.06 \\
\hline SCEA 1 & $<-$ & SCEA & 1.000 & 0.390 & & & \\
\hline SCEA 2 & $<-$ & SCEA & 0.487 & 0.336 & 0.076 & 6.368 & 0.00 \\
\hline SCEA 3 & $<-$ & SCEA & 0.345 & 0.320 & 0.055 & 6.271 & 0.00 \\
\hline SCEB 1 & $<-$ & SCEB & 1.000 & 0.655 & & & \\
\hline SCEB 2 & $<-$ & SCEB & 0.923 & 0.531 & 0.083 & 11.170 & 0.00 \\
\hline SCEB 3 & $<-$ & SCEB & 0.714 & 0.436 & 0.069 & 10.305 & 0.00 \\
\hline
\end{tabular}

\subsection{Markov Chain Monte Carlo Confirmatory Factor Analysis (MCMC CFA), a Bayesian Approach}

Keeping in mind that tested constructs consist of three-point scale and two-point scale ordinal measures, and a violation of normal distribution assumption was detected, a Bayesian estimation procedure was conducted in order to validate the first-order factor model. The results were based on 62,500 samples collected after 500 burn-in samples, for a total of 63,000 samples after the thinning process. The posterior predictive value of the model was 0.50 , indicating that the model has a good fit. Additionally, the potential scale reduction (PSR) was 1.0010 indicating that convergence was achieved. 
As shown in Table 7, all direct effects on latent dimensions (awareness, attitudes and behavior) are positive and significant, with regression coefficients that are almost identical to unstandardized estimates in the first-order factor model (see Table 6). In addition, graphical representation of the posterior distribution verifies positive direct effects (see Figure 2). Furthermore, a positive correlation between SCEA and SCEB was also confirmed. Similar to CFA, the Bayesian estimation did not register a correlation between SCEB and CEW, nor between SCEA and CEW.

Table 7. Summary of Direct Relationship and Correlation.

\begin{tabular}{cccccccccc}
\hline & & & Mean & S.E. & S.D. & $\begin{array}{c}\text { 95\% Lower } \\
\text { Bund }\end{array}$ & $\begin{array}{c}\text { 95\% Upper } \\
\text { Bund }\end{array}$ & Min & Max \\
\hline CEW 2 & $<-$ & CEW & 3.637 & 0.07 & 1.54 & 1.691 & 7.674 & 1.101 & 13.596 \\
\hline SCEA 2 & $<-$ & SCEA & 0.487 & 0 & 0.078 & 0.349 & 0.655 & 0.22 & 0.953 \\
\hline SCEA 3 & $<-$ & SCEA & 0.346 & 0 & 0.056 & 0.246 & 0.466 & 0.15 & 0.679 \\
\hline SCEB 2 & $<-$ & SCEB & 0.926 & 0 & 0.084 & 0.77 & 1.1 & 0.618 & 1.347 \\
\hline SCEB 3 & $<-$ & SCEB & 0.714 & 0 & 0.07 & 0.582 & 0.858 & 0.441 & 1.145 \\
\hline SCEA & $<->$ & SCEB & 0.078 & 0 & 0.01 & 0.06 & 0.10 & 0.04 & 0.124 \\
\hline SCEA & $<->$ & CEW & 0.011 & 0 & 0.004 & 0.00 & 0.02 & 0.001 & 0.033 \\
\hline CEW & $<->$ & SCEB & 0.014 & 0 & 0.005 & 0.01 & 0.03 & 0.002 & 0.038 \\
\hline
\end{tabular}
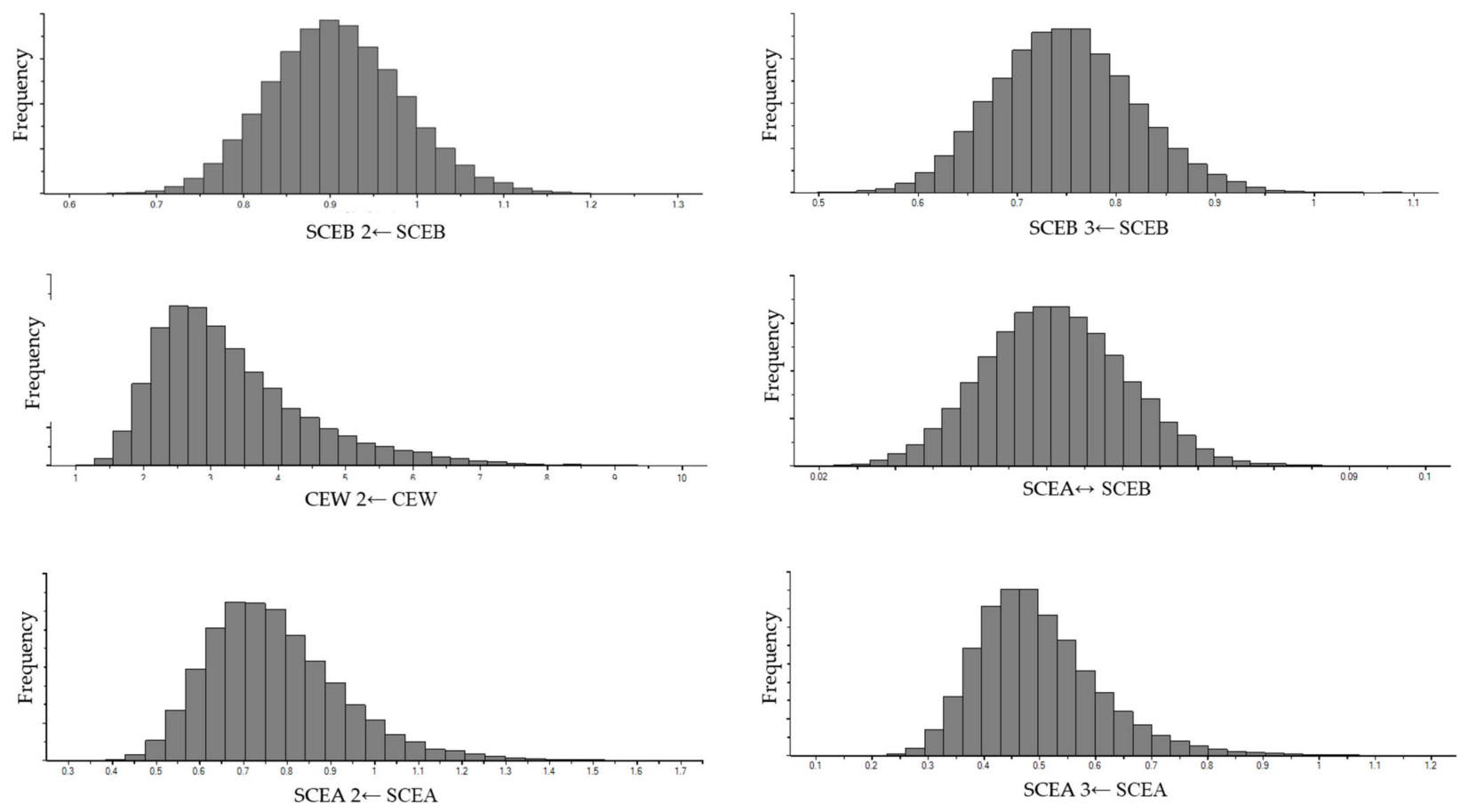

Figure 2. Posterior distribution.

\section{Discussion}

\subsection{Theoretical Implications}

The previous research confirmed that education on current issues of circular economy is needed for Generation $\mathrm{Z}$ to become aware of the most important circular concepts as consumers, which in turn would enable them to be the agents of future change towards a circular society [65]. The present research results do not confirm these findings in part due to the explorative nature of the research, but this also opens up a new avenue for future 
research on moderating the role of awareness in the relationship between attitudes and behavior. The results of the study confirm previous findings that there is no significant relation between knowledge or concern regarding environmental issues and readiness for paying extra for carbon-friendly products [69]. Present results demonstrate that there is a significant relation between attitudes and behavior, while there is no significant relation between awareness and attitudes nor between awareness and behavior. The contribution of the study mainly relates to the deployment of two-point and three-point scales for enhanced usability and feedback from the respondents, which then necessitated the deployment of Bayesian, MCMC CFA. The deployment of MCMC CFA is a novelty in this field of research and has rarely been used before.

Contrary to the previous research, where Generation $\mathrm{Z}$ has been segmented regarding price sensitivity and convenience (extrinsic eco-product cues) as well as attitudes and awareness of the health benefits in relation to eco-food products [64], the present research does not deal with price sensitivity and convenience as extrinsic cues but focuses instead only on attitudes and awareness in relation to the eco-products, as well as concrete behaviors of Generation Z. It has been deemed that these two extrinsic cues (price sensitivity and convenience) are more directed towards the operationalization of concrete marketing strategy, rather than contributing to the body of scholarly research in the field of sustainable consumption.

Sustainability attitudes have previously been researched from the perspective of dichotomies: positive and negative environmental attitudes and how they impact environmental and non-environmental travel priorities [59]. However, the present research does not differentiate between these two types of attitudes but expends this research by including awareness as an additional construct. Several studies in the field of eco products and brands deal with the attitude-behavior link by examining the greenwashing phenomena, which is to be observed in certain brands where the communicated values do not translate to real sustainability-oriented value creation [70,71]. However, we posit here that the concept of awareness needs to be included in future studies on greenwashing, as attitudes and behavior alone cannot provide a satisfactory explanation of the greenwashing effect, while awareness of certain issues seems much more suitable for this purpose. Greenwashing as a phenomenon actually rests on the fact that consumers are aware of what value a green product should provide and are additionally aware that certain products do not fulfill these requirements although being advertised as such.

It appears that an abundance of education-related literature on environmental attitudes and awareness examines in detail the impact of knowledge and education regarding environmental issues on both school children's attitudes as well as awareness [72-74]. However, there is a paucity of educational research that includes behavior (e.g., consumer behavior) as the most important construct for researching education-related phenomena [75]. The present research seeks to start a fruitful bridge between educational research which deals with environmental knowledge and attitudes on one side and marketing and management research dealing with attitudes and consumer behavior.

The previous research on sustainable consumption has established the direct link between sustainability-oriented attitudes and sustainability-oriented behavior [71,76]. Further studies have also established the link between the awareness of environmental labels and consumer behavior by deploying chi-squared independence criterion and correlation analysis [77]. The present study contributes to this stream of literature by providing further evidence on the link between sustainability-oriented attitudes and sustainability-oriented behavior, while the link between awareness of environmental issues and behavior could not be confirmed.

\subsection{Practical Implications}

There are useful practical approaches in the literature regarding the media and formats, such as social media influencers, which Generation $\mathrm{Z}$ follows, which can be used for promoting circular economy [78]. Influencers can both increase awareness among 
Generation Z but can probably also influence directly Generation Z's attitudes. The results of the study regarding the importance of awareness of circular economy issues however do not confirm the practical importance of awareness-raising for consumer behavior. Further research should therefore better explain how important influencers in social media actually are in the consumer behavior of Generation $Z$, both regarding the impact on their attitudes as well as awareness.

Understanding the connection between consumer attitudes, awareness and behavior are very important in a sustainable and circular economy, as public policies in these areas often rely on the notion that increasing consumer awareness about sustainable products will lead to a change in consumer behavior $[79,80]$. The present study addresses this important research area by providing an explorative analysis of consumer behavior of Generation $\mathrm{Z}$ regarding eco-products, which is explained by their sustainability and circular economy attitudes and circular economy awareness. The present study also seeks to provide a sound scientific grounding on which to build future public communication policies in the field of sustainability. Marketing managers should track Generation Z's attitudes regarding sustainability and circular economy issues in order to be able to predict and explain their behavior in relation to green products. The design of informational campaigns as well as education programs should involve primarily attitudinal components and less awareness-related components.

\subsection{Limitations and Future Research Directions}

Respondents are shown to overstate their circular economy and sustainability-oriented concern when no actual commitment is expected from them [81]. Therefore, the part of the results related to attitudes should be interpreted with caution. The wording of the items SCEA 1, SCEA 2, SCEB 1 and SCEB 2 was to a certain degree leading, not stating the opposite side of the argument, which could have affected the validity of the answers. The items SCEA 1 and SCEA 2 have both been double-barreled items, asking participants more than one thing at once, not allowing for a separate answer to each one of the two topics the question deals with. This could potentially lead to an inaccurate measurement of the attitudes in question.

The research is focused on the circular economy awareness, sustainability and circular economy attitudes and sustainability and circular economy behavior of generation $\mathrm{Z}$. Therefore, the results of the research cannot be translated to other generational cohorts without conducting new research. This makes any systemic change in consumption patterns based on these results impossible without further research. In addition, other behaviorrelated constructs were not been taken into account, which limits the transferability of results to other research communities. Other behavior-related constructs, used in previous research, are perceived value, social norms, perceived availability, perceived effectiveness, perceived behavioral control $[82,83]$, all of which can be used to expand the present research in the future studies.

The direct impact of sustainability-oriented knowledge on sustainability-oriented attitudes has been established in the previous literature, as well as the impact of education on environmental awareness [73,74]. Therefore, future research should expand the present research and include sustainability-oriented knowledge and education as latent constructs which are related to sustainability-oriented attitudes and awareness. The research should also enable policymakers and educators to support the future generations of decisionmakers to make a sound decision in terms of circular economy ethics, both in terms of social policies as well as on the consumer's level, by developing innovative educational campaigns targeting attitudes of the students.

\section{Conclusions}

The research results demonstrate the significance of the link between attitudes and behavior regarding eco products which are oriented towards both sustainability as well as the circular economy. However, it falls short at confirming the importance of the link 
between attitudes and awareness and behavior and awareness. Future studies should therefore examine in more detail other relevant variables, e.g., from the theory of planned behavior: attitudes towards behavior and subjective norms which influence intention, with perceived behavioral control acting as a moderating variable, with intention having a direct influence on behavior [84].

The present research makes a twofold contribution to the academic discussion in the previous literature. Firstly, it contributes to the research on the generational cohorts and generational cohort theory for sustainability by presenting the relation between Generation Z's consumer behavior related to eco products, sustainability and circular economy attitudes and circular economy awareness. Secondly, it presents a precise model of interaction between consumer attitudes, consumer awareness and consumer behavior for sustainability and circular economy, as a contribution to the sustainable consumption literature. By offering a new perspective on these two emerging research streams, the research also tries to position both Generation Z's consumer behavior regarding eco-products as well as the circular economy in the wider literature on attitudes-behavior gap for sustainability and sustainable consumption. The research results confirm that there is a statistically significant correlation between Sustainability and circular economy attitudes (SCEA) and Sustainability and circular economy behavior (SCEB). The results also confirm that there is no statistically significant correlation between Sustainability and circular economy attitudes (SCEA) and Circular economy awareness (CEW), nor between Sustainability and circular economy behavior (SCEB) and Circular economy awareness (CEW).

The results demonstrate that future efforts regarding degrowth and the reduction of overconsumption need to take into account the mechanisms underlying sustainable consumption (e.g., attitudes) in order to communicate with the consumers in a more efficient and effective way. One way to do this is to have a differentiated sustainable consumption communication strategy for different generational cohorts, as well as for different types of attitudes.

Keeping in mind that the Agenda 2030, adopted by the General Assembly of the UN [85], calls for raising awareness on sustainable development goals in Goals 12.8 and 13.3 , it is of utmost importance for the theory and practice of sustainable development that the precise impact of attitudes and awareness on consumer behavior be understood. The article offers a contribution to the theory of sustainable consumption but also offers a sound underpinning for future practice-oriented marketing strategies of eco-products.

Circular economy is an important and emerging field in research and education for sustainability. Students need to be able to translate sustainable development principles in their everyday personal and professional activities, both as individuals as well as in groups. Keeping in mind the need for educating Generation $\mathrm{Z}$ on circular economy issues [47], the model presented in this research should also sensitize present educators and decisionmakers that the provision of knowledge and competencies in relation to sustainability and the circular economy does not directly lead to a behavioral change in students, but attitudes and awareness play an important role in this process. In other words, the provision of competencies and knowledge regarding sustainability and circular economy on the part of the education system needs to be internalized in Generation Z as both Gen Z's individuals as well Gen Z's group attitudes in order for them to have an impact on the whole generation and the future society.

Author Contributions: Conceptualization, T.M.N. and M.Đ.; methodology, M.M.; software, M.M.; validation, T.M.N., M.M. and M.Đ.; formal analysis, I.P.; investigation, M.M.; resources, T.M.N.; data curation, I.P.; writing —original draft preparation, T.M.N. and I.P.; writing—review and editing, T.M.N and N.L.; visualization, I.P.; supervision, T.M.N. and N.L.; project administration, T.M.N.; funding acquisition, T.M.N. All authors have read and agreed to the published version of the manuscript.

Funding: This research received no external funding.

Data Availability Statement: Not applicable. 


\begin{abstract}
Acknowledgments: The authors would like to thank the students of primary and secondary schools as well as universities and colleges who were kind enough to participate in the study and provide valuable insights into Generation Z's attitudes and behavior.

Conflicts of Interest: The authors declare no conflict of interest. The funders had no role in the design of the study; in the collection, analyses, or interpretation of data; in the writing of the manuscript, or in the decision to publish the results.
\end{abstract}

\title{
References
}

1. Debevec, K.; Schewe, C.D.; Madden, T.J.; Diamond, W.D. Are today's millennials splintering into a new generational cohort? Maybe! J. Consum. Behav. 2013, 12, 20-31. [CrossRef]

2. Thach, L.; Riewe, S.; Camillo, A. Generational cohort theory and wine: Analyzing how gen $\mathrm{Z}$ differs from other American wine consuming generations. Int. J. Wine Bus. Res. 2020, 33, 1-27. [CrossRef]

3. Eastman, J.K.; Liu, J. The impact of generational cohorts on status consumption: An exploratory look at generational cohort and demographics on status consumption. J. Consum. Mark. 2012, 29, 93-102. [CrossRef]

4. Deloitte The Deloitte Global Millennial Survey 2020. Available online: https://www2.deloitte.com/global/en/pages/aboutdeloitte/articles/millennialsurvey.html (accessed on 30 August 2021).

5. Statistical Office of the Republic of Serbia Population Pyramid. Available online: https://www.stat.gov.rs/en-US/vizuelizacija/ interaktivni-grafikoni/mapa (accessed on 16 October 2021).

6. Dimock, M. Defining generations: Where Millennials end and Generation Z begins. Pew Res. Cent. 2019, 17, 1-7.

7. Spitznagel, E. Generation $\mathrm{Z}$ is bigger than millennials-And they're out to change the world. New York Post. 25 January 2020. Available online: https://nypost.com/2020/01/25/generation-z-is-bigger-than-millennials-and-theyre-out-to-change-theworld / (accessed on 15 August 2021).

8. Cheung, M.L.; Leung, W.K.S.; Chan, H. Driving healthcare wearable technology adoption for Generation Z consumers in Hong Kong. Young Consum. 2020, 22, 10-27. [CrossRef]

9. Mamula, T.; Popovic-Pantic, S. Relationship between innovativeness and strategic planning: Empirical research. Industrija 2015, 43, 47-65. [CrossRef]

10. Mamula Nikolic, T. Nova Generacija Potrošača i Lidera; Metropolitan University and iLearn d.o.o.: Belgrade, Serbia, 2021.

11. Van der Bergh, J.; Pallini, K. Marketing to Generation Z. Res. World 2018, 70, 18-23. [CrossRef]

12. Confente, I.; Scarpi, D.; Russo, I. Marketing a new generation of bio-plastics products for a circular economy: The role of green self-identity, self-congruity, and perceived value. J. Bus. Res. 2020, 112, 431-439. [CrossRef]

13. Kollmuss, A.; Agyeman, J. Mind the gap: Why do people act environmentally and what are the barriers to pro-environmental behavior? Environ. Educ. Res. 2002, 8, 239-260. [CrossRef]

14. Brusselaers, J.; Bracquene, E.; Peeters, J.; Dams, Y. Economic consequences of consumer repair strategies for electrical household devices. J. Enterp. Inf. Manag. 2019, 33, 747-767. [CrossRef]

15. Magnier, L.; Mugge, R.; Schoormans, J. Turning ocean garbage into products-Consumers' evaluations of products made of recycled ocean plastic. J. Clean. Prod. 2019, 215, 84-98. [CrossRef]

16. Abdul-Wahab, S.A. A preliminary investigation into the environmental awareness of the Omani public and their willingness to protect the environment. Am. J. Environ. Sci. 2008, 4, 39-49.

17. Moon, S.; Bergey, P.K.; Bove, L.L.; Robinson, S. Message framing and individual traits in adopting innovative, sustainable products (ISPs): Evidence from biofuel adoption. J. Bus. Res. 2016, 69, 3553-3560. [CrossRef]

18. Garvey, A.M.; Bolton, L.E. Eco-product choice cuts both ways: How proenvironmental licensing versus reinforcement is contingent on environmental consciousness. J. Public Policy Mark. 2017, 36, 284-298. [CrossRef]

19. Mazzocchi, C.; Orsi, L.; Sali, G. Consumers' Attitudes for Sustainable Mountain Cheese. Sustainability 2021, 13, 1743. [CrossRef]

20. Tagliafierro, N. The Circular Economy at Enel X. Symph. Emerg. Issues Manag. 2020, 101-116. [CrossRef]

21. Festinger, L. A Theory of Cognitive Dissonance; Stanford University Press: Stanford, CA, USA, 1957; Volume 2. [CrossRef]

22. Hares, A.; Dickinson, J.; Wilkes, K. Climate change and the air travel decisions of UK tourists. J. Transp. Geogr. 2010, 18, 466-473. [CrossRef]

23. Diekmann, A.; Preisendörfer, P. Green and greenback: The behavioral effects of environmental attitudes in low-cost and high-cost situations. Ration. Soc. 2003, 15, 441-472. [CrossRef]

24. Mattar, L.; Abiad, M.G.; Chalak, A.; Diab, M.; Hassan, H. Attitudes and behaviors shaping household food waste generation: Lessons from Lebanon. J. Clean. Prod. 2018, 198, 1219-1223. [CrossRef]

25. Juvan, E.; Dolnicar, S. The attitude-behaviour gap in sustainable tourism. Ann. Tour. Res. 2014, 48, 76-95. [CrossRef]

26. Youn, C.; Jung, H.J. Semantic Network Analysis to Explore the Concept of Sustainability in the Apparel and Textile Industry. Sustainability 2021, 13, 3813. [CrossRef]

27. Han, J.; Lee, M.; Hwang, Y.-S. Tourists' Environmentally Responsible Behavior in Response to Climate Change and Tourist Experiences in Nature-Based Tourism. Sustainability 2016, 8, 644. [CrossRef]

28. Charter, M.; Young, A.; Kielkiewicz-Young, A.; Belmane, I. Integrated product policy and eco-product development. In Sustainable Solutions; Routledge: Abingdon-on-Thames, UK, 2017; pp. 98-116. 
29. Ünal, E.; Shao, J. A taxonomy of circular economy implementation strategies for manufacturing firms: Analysis of 391 cradle-tocradle products. J. Clean. Prod. 2019, 212, 754-765. [CrossRef]

30. Ghosh, K.; Jones, B.H. Roadmap to Biodegradable Plastics-Current State and Research Needs. ACS Sustain. Chem. Eng. 2021, 9, 6170-6187. [CrossRef]

31. Żelaziński, T.; Słoma, J.; Skudlarski, J.; Ekielski, A. The rape pomace and microcrystalline cellulose composites made by press processing. Sustainability 2020, 12, 1311. [CrossRef]

32. Casamayor, J.L.; Su, D. Investigation of a Process to Eco-Design Led Lighting Products to Enhance the Adoption of Eco-Design Methods and Tools by Industry. Sustainability 2021, 13, 4512. [CrossRef]

33. Thatta, S.; Polisetty, A. The Future Is Circular: A Case Study on MUD Jeans. FIIB Bus. Rev. 2020, 9, 2319714520950163. [CrossRef]

34. Żelaziński, T.; Ekielski, A.; Siwek, A.; Dardziński, L. Characterisation of corn extrudates with the addition of brewers' spent grain as a raw material for the production of functional batters. Acta Sci. Pol. Technol. Aliment. 2017, 16, 247-254.

35. Topic, M.; Mitchell, B. Generation Z E Consumer Trends in Environmental Packaging; The Retail Institute, Leeds Beckett University: Leeds, UK, 2019.

36. Perić, N.; Mamula NIkolic, T.; Delić, T. Analysis of Attitudes of GenZ Toward Media and Consumption: The Region of Balkans. Marketing 2020. ahead-of-print. [CrossRef]

37. Dimitriou, C.K.; AbouElgheit, E. Understanding generation Z's travel social decision-making. Tour. Hosp. Manag. 2019, 25, 311-334. [CrossRef]

38. Francis, T.; Hoefel, F. True Gen': Generation Z and Its Implications for Companies. Available online: https: / www.mckinsey.com/ industries/consumer-packaged-goods/our-insights/true-gen-generation-z-and-its-implications-for-companies (accessed on 20 January 2022).

39. Priporas, C.-V.; Stylos, N.; Fotiadis, A.K. Generation Z consumers' expectations of interactions in smart retailing: A future agenda. Comput. Hum. Behav. 2017, 77, 374-381. [CrossRef]

40. Prakash, G.; Choudhary, S.; Kumar, A.; Garza-Reyes, J.A.; Khan, S.A.R.; Panda, T.K. Do altruistic and egoistic values influence consumers' attitudes and purchase intentions towards eco-friendly packaged products? An empirical investigation. J. Retail. Consum. Serv. 2019, 50, 163-169. [CrossRef]

41. Taufique, K.M.R.; Polonsky, M.J.; Vocino, A.; Siwar, C. Measuring consumer understanding and perception of eco-labelling: Item selection and scale validation. Int. J. Consum. Stud. 2019, 43, 298-314. [CrossRef]

42. Auliandri, T.A.; Thoyib, A.; Rohman, F.; Rofiq, A. Does green packaging matter as a business strategy. Explor. Young Consum. Consum. Emerg. Mark.. Probl. Perspect. Manag. 2018, 16, 376-384.

43. Orzan, G.; Cruceru, A.F.; Bălăceanu, C.T.; Chivu, R.-G. Consumers' behavior concerning sustainable packaging: An exploratory study on Romanian consumers. Sustainability 2018, 10, 1787. [CrossRef]

44. Kardos, M.; Gabor, M.R.; Cristache, N. Green marketing's roles in sustainability and ecopreneurship. Case study: Green packaging's impact on Romanian young consumers' environmental responsibility. Sustainability 2019, 11, 873. [CrossRef]

45. Gaworski, M.; Borowski, P.; Zajkowska, M. Attitudes of a group of young Polish consumers towards selected features of dairy products. Agron. Res. 2021, 19, 1023-1038. [CrossRef]

46. Blomberg, L.; Furman, J. Enhancing Fast Fashion Brands Through Environmentally Sustainable Efforts: An Explorative Study on Generation Z's Perceptions towards Circular Economy Initiatives and Its Impact on Customer-Based Brand Equity; Lulea University of Technology: Lulea, Sweden, 2021.

47. Lakatos, E.; Dan, V.; Cioca, L.; Bacali, L.; Ciobanu, A. How Supportive Are Romanian Consumers of the Circular Economy Concept: A Survey. Sustainability 2016, 8, 789. [CrossRef]

48. Ratner, S.; Lazanyuk, I.; Revinova, S.; Gomonov, K. Barriers of Consumer Behavior for the Development of the Circular Economy: Empirical Evidence from Russia. Appl. Sci. 2021, 11, 46. [CrossRef]

49. Stern, P.C. New environmental theories: Toward a coherent theory of environmentally significant behavior. J. Soc. Issues 2000, 56, 407-424. [CrossRef]

50. Ajzen, I. The theory of planned behavior: Frequently asked questions. Hum. Behav. Emerg. Technol. 2020, 2, 314-324. [CrossRef]

51. Baird, T.; Hall, C.M.; Castka, P. New Zealand winegrowers attitudes and behaviours towards wine tourism and sustainable winegrowing. Sustainability 2018, 10, 797. [CrossRef]

52. Capitello, R.; Bazzani, C.; Begalli, D. Consumer personality, attitudes and preferences in out-of-home contexts. Int. J. Wine Bus. Res. 2019, 31, 48-67. [CrossRef]

53. Alibabic, V.; Jokic, S.; Mujic, I.; Rudic, D.; Bajramovic, M.; Jukic, H. Attitudes, behaviors, and perception of consumers' from northwestern Bosnia and Herzegovina toward food products on the market. Procedia Soc. Behav. Sci. 2011, 15, 2932-2937. [CrossRef]

54. Jorge, E.; Lopez-Valeiras, E.; Gonzalez-Sanchez, M.B. The role of attitudes and tolerance of ambiguity in explaining consumers' willingness to pay for organic wine. J. Clean. Prod. 2020, 257, 120601. [CrossRef]

55. Esteban Ibáñez, M.; Musitu Ferrer, D.; Amador Muñoz, L.V.; Claros, F.M.; Olmedo Ruiz, F.J. University as Change Manager of Attitudes towards Environment (The Importance of Environmental Education). Sustainability 2020, 12, 4568. [CrossRef]

56. Kovačič, G.; Brečko Grubar, V. Knowledge of sustainable development among geography students in Slovenia. Acta Geogr. Slov. 2016, 56, 101-119. [CrossRef] 
57. Kamenidou, I.C.; Mamalis, S.A.; Pavlidis, S.; Bara, A.E.-Z.G. Segmenting the Generation Z Cohort University Students Based on Sustainable Food Consumption Behavior: A Preliminary Study. Sustainability 2019, 11, 837. [CrossRef]

58. Bumbac, R.; Bobe, M.; Procopie, R.; Pamfilie, R.; Giușă, S.; Enache, C. How Zoomers' Eating Habits Should be Considered in Shaping the Food System for 2030-A Case Study on the Young Generation from Romania. Sustainability 2020, $12,7390$. [CrossRef]

59. Mamula Nikolić, T.; Pantić, S.P.; Paunović, I.; Filipović, S. Sustainable Travel Decision-Making of Europeans: Insights from a Household Survey. Sustainability 2021, 13, 1960. [CrossRef]

60. Gardiner, S.; King, C.; Grace, D. Travel decision making: An empirical examination of generational values, attitudes, and intentions. J. Travel Res. 2013, 52, 310-324. [CrossRef]

61. Szromek, A.R.; Hysa, B.; Karasek, A. The Perception of Overtourism from the Perspective of Different Generations. Sustainability 2019, 11, 7151 .

62. Miskolczi, M.; Jászberényi, M.; Tóth, D. Technology-Enhanced Airport Services-Attractiveness from the Travelers' Perspective. Sustainability 2021, 13, 705. [CrossRef]

63. Lillemo, S.C. Measuring the effect of procrastination and environmental awareness on households' energy-saving behaviours: An empirical approach. Energy Policy 2014, 66, 249-256. [CrossRef]

64. Su, C.H.J.; Tsai, C.H.K.; Chen, M.H.; Lv, W.Q. U.S. Sustainable Food Market Generation Z Consumer Segments. Sustainability $2019,11,3607$.

65. Krasulja, N.; Ilić, D.T.; Marković, B.M. Basic principles of circular economy with special focus on sustainable consumption "y" and "z" generation. Ecoforum J. 2020, 9, 2.

66. IBM. IBM SPSS Statistics for Windows; IBM Corporation: New York, NY, USA, 2019; Volume 26.

67. IBM. IBM SPSS Amos; Amos Development Corporation: Wexford, PA, USA, 2015.

68. Veal, A.J. Research Methods for Leisure and Tourism, 5th ed.; Pearson Education: Harlow, UK, 2018.

69. Penz, E.; Hofmann, E. What Stirs Consumers to Purchase Carbon-Friendly Food? Investigating the Motivational and Emotional Aspects in Three Studies. Sustainability 2021, 13, 8377. [CrossRef]

70. Leckie, C.; Rayne, D.; Johnson, L.W. Promoting Customer Engagement Behavior for Green Brands. Sustainability 2021, $13,8404$. [CrossRef]

71. Braga Junior, S.; Martínez, M.P.; Correa, C.M.; Moura-Leite, R.C.; Da Silva, D. Greenwashing effect, attitudes, and beliefs in green consumption. RAUSP Manag. J. 2019, 54, 226-241. [CrossRef]

72. Janmaimool, P.; Khajohnmanee, S. Roles of environmental system knowledge in promoting university students' environmental attitudes and pro-environmental behaviors. Sustainability 2019, 11, 4270. [CrossRef]

73. Coertjens, L.; Boeve-de Pauw, J.; De Maeyer, S.; Van Petegem, P. Do schools make a difference in their students'environmental attitudes and awareness? Evidence from PISA 2006. Int. J. Sci. Math. Educ. 2010, 8, 497-522. [CrossRef]

74. Hoyos, D.; Mariel, P.; Hess, S. Incorporating environmental attitudes in discrete choice models: An exploration of the utility of the awareness of consequences scale. Sci. Total Environ. 2015, 505, 1100-1111. [CrossRef] [PubMed]

75. Müderrisoglu, H.; Altanlar, A. Attitudes and behaviors of undergraduate students toward environmental issues. Int. J. Environ. Sci. Technol. 2011, 8, 159-168. [CrossRef]

76. Riskos, K.; Dekoulou, P.; Mylonas, N.; Tsourvakas, G. Ecolabels and the Attitude-Behavior Relationship towards Green Product Purchase: A Multiple Mediation Model. Sustainability 2021, 13, 6867. [CrossRef]

77. Daniuseviciute-Brazaite, L. Education for Sustainable Development: Sustainability-Related Food Labels. Sustainability 2021, 13, 8117. [CrossRef]

78. Kale, E. Influencer Marketing in Circular Economy; Masarykova Univerzita, Ekonomicko-Správní Fakulta: Brno, Czechia, 2021.

79. Lambarraa-Lehnhardt, F.; Ihle, R.; Elyoubi, H. How Successful Is Origin Labeling in a Developing Country Context? Moroccan Consumers' Preferences toward Local Products. Sustainability 2021, 13, 8433. [CrossRef]

80. Liu, Q.; Li, H.-M.; Zuo, X.-L.; Zhang, F.-F.; Wang, L. A survey and analysis on public awareness and performance for promoting circular economy in China: A case study from Tianjin. J. Clean. Prod. 2009, 17, 265-270. [CrossRef]

81. Ercan, O.; Bilen, K. A research on electronic waste awareness and environmental attitudes of primary school students. Anthropol. 2014, 17, 13-23. [CrossRef]

82. Alam, S.S.; Ahmad, M.; Ho, Y.-H.; Omar, N.A.; Lin, C.-Y. Applying an Extended Theory of Planned Behavior to Sustainable Food Consumption. Sustainability 2020, 12, 8394. [CrossRef]

83. Garay, L.; Font, X.; Corrons, A. Sustainability-Oriented Innovation in Tourism: An Analysis Based on the Decomposed Theory of Planned Behavior. J. Travel Res. 2018, 58, 622-636. [CrossRef]

84. Bosnjak, M.; Ajzen, I.; Schmidt, P. The Theory of Planned Behavior: Selected Recent Advances and Applications. Eur J Psychol 2020, 16, 352-356. [CrossRef] [PubMed]

85. UN. Transforming Our World: The 2030 Agenda for Sustainable Development; United Nations: New York, NY, USA, 2015. 